\title{
Integrated Effect of Fertilizers on Beans Cultivated in Alluvial Soil
}

\author{
K. F. Fouda, A. M. El-Ghamry, Z. M. El-Sirafy and I. H. A. Klwet \\ Soil. Dept., Fac. of Agric., Mansoura Univ., Mansoura, Egypt
}

\begin{abstract}
A FIELD experiment was carried out using bean (Phaseolus vulgaris L.). CV Bohera, during season 2015 at the Agric. Exp. Station of El-Mansoura Univ. to study integrated effect of fertilizers on beans cultivated in alluvial soil. The treatments were NPK $75 \%$, NPK $100 \%$, NPK $75 \%+$ compost and NPK $100 \%+$ compost, in addition to control. The results showed that the best treatment was NPK $100 \%+$ compost, compared to control, which gave the highest values of vegetative growth parameter (pod diameter, pod length and plant height), and enhanced quality parameters (NPK $\%$, carbohydrate $\%$ and protein $\%$ of seed), also improved chlorophyll content of bean plant the NPK $100 \%+$ compost treatment not only enhanced NPK \% in leaves and increased yield but also increased available NPK in soil.
\end{abstract}

\section{Introduction}

Bean (Phaseolus vulgaris L.) is one of the most important vegetable and fresh market crop in the world and bean contains a source of dietary, fibers calories, proteins, minerals and vitamins for millions of people in countries worldwide, (Shehata et al., 2011). In Egypt, bean plant is considered one of the important vegetable crops cultivated and the total cultivated area of bean plants is (60000 feddans) which produces annually about 28530 tons (FAO, 2010).

Improved soil fertility requires the use of organic and inorganic resources in an integrated manner in order to increase the efficiency of using them and thus increase productivity of the crops. In last years, raising the efficiency of used mineral fertilizers or chemical fertilizers, either natural or synthetic is needed to increase crop yields, but their high cost is not always affordable to poor farmers (Vanlauwe et al., 2000) .

Phosphorus, nitrogen and potassium are major nutrients, especially for legumes, phosphorus and nitrogen can play an important role in improving plant growth and phosphate uptake efficiency by releasing phosphorus from rock or tri-calcium phosphate (El-Gizawy and Mehasen , 2009). Potassium is one of the essential elements in plants where there are relationships between yield and potassium applications (El-Bramawy and Shaban, 2010).

The use of organic fertilizers together with chemical fertilizers, compared to the addition of organic fertilizers alone, had a higher positive effect on microbial biomass and hence soil health and application of organic manure in combination with chemical fertilizer has been reported to increase absorption of $\mathrm{N}, \mathrm{P}$ and $\mathrm{K}$ in leaf tissue in the plant, compared to chemical fertilizer alone (Bokhtiar and Sakurai, 2005).

Researchers observed that application of organic matter significantly has an impact on the chemical, physical and biological properties of the soil, and organic matter of manure is considerd a source of major plant nutrients such as N, P and potassium $(\mathrm{K})$. It also provides many of the secondary nutrients that plants require. Benefits of compost amendments added to soil include $\mathrm{pH}$ depressing and faster infiltration rate due to enhanced soil aggregation (Liang et al., 2011).,

Significant higher soil enzyme activities resulting from applied compost to soil and plants not only generate a better nutritional state which reflects positively on growth and yield of plants, but also, positively influences other soil properties, such as water holding capacity and aeration (Pagliai et al., 2004). 
There are other agronomic benefits of composts application, such as high levels of soil-borne diseases suppression and removal of soil salinity. All composts work as a 'slowrelease fertilizer' whereas chemical fertilizers release their nutrients faster and compost contains elements play an important role to growing plants (Sinha and Rajiv, 2003).

The objective of this research is using some fertilizers treatments which obtain integrated effect of fertilizers on beans cultivated in alluvial soil for increasing growth, yield and quality of bean plant.

\section{Materials and Methods}

Field experiment was carried out planting Bean (Phaseolus vulgaris L.). CV Bohera, during season of 2015 at the Agric. Exp. Station of ElMansoura Univ.to study integrated effect of fertilizers on bean plants cultivated in alluvial soil. The field experiment was an application of the data obtained from field.

\section{Compost}

The compost used was plant waste in this study, it was added at rate of $20 \mathrm{~m}^{3} / \mathrm{fed}^{-1}$.

TABLE 1. Analysis of compost Sample in experiment

\begin{tabular}{|c|c|c|c|c|c|c|c|c|}
\hline $\operatorname{EC~}(1: 10) \mathrm{dsm}^{-1}$ & pH (1:5) & ОМ \% & OC \% & T.N \% & $\mathrm{C} / \mathrm{N}$ ratio & T.P \% & T.K \% & SP \% \\
\hline 3.69 & 6.09 & 38.2 & 22.2 & 1.39 & $1: 16$ & 0.51 & 0.45 & 178 \\
\hline
\end{tabular}

TABLE 2. Soil characteristics before planting in experiment

\begin{tabular}{|c|c|c|c|c|c|c|c|c|c|c|c|c|}
\hline \multicolumn{13}{|c|}{ Soil characters } \\
\hline \multicolumn{5}{|c|}{ Particle size distribution (\%) } & \multicolumn{5}{|c|}{ Chemical and physical properties } & \multicolumn{3}{|c|}{ Available (mg. kg-1) } \\
\hline $\begin{array}{c}\text { C. } \\
\text { sand }\end{array}$ & $\begin{array}{c}\text { F. } \\
\text { sand }\end{array}$ & Silt & Clay & $\begin{array}{l}\text { Texture } \\
\text { class }\end{array}$ & $\begin{array}{c}\text { EC } \\
\text { dSm }^{-1} \\
(\mathbf{1 : 5})\end{array}$ & $\begin{array}{c}\text { pH } \\
(1: 2.5)\end{array}$ & SP \% & $\begin{array}{c}\text { OM } \\
\%\end{array}$ & $\begin{array}{c}\text { Total } \\
\mathrm{CaCO}_{3} \%\end{array}$ & $\mathbf{N}$ & $\mathbf{P}$ & $\mathbf{K}$ \\
\hline 3.98 & 26.35 & 35.51 & 34.16 & Clay loam & 1.07 & 8.12 & 62.5 & 1.73 & 4.16 & 46.5 & 10.14 & 150.3 \\
\hline
\end{tabular}

\section{Mineral fertilizers}

Nitrogen fertilizer was ammonium sulphate $\left(\mathrm{NH}_{4}\right)_{2} \mathrm{SO}_{4}$ added at a rate of $100 \mathrm{Kg} \mathrm{N}$.fed ${ }^{-1}$ as recommended dose at two equal doses and slow release fertilizer (sulfur coated) added at a rate of $187.5 \mathrm{~kg}$ sulfur coated urea. The recommended dose of phosphorus and potassium fertilizers were applied as super phosphate $(7 \% \mathrm{P})$ and potassium sulphate $(40 \% \mathrm{~K})$ at rates of $200 \mathrm{Kg} \mathrm{P}_{2} \mathrm{O}_{5}$ fed $^{-1}$ and $50 \mathrm{Kg} \mathrm{K}_{2} \mathrm{O}$ fed $^{-1}$, respectively.

\section{Experimental design}

The design was complete block design where: Main plots: 1- Control 2- NPK $75 \%$, 3- NPK $100 \%$ 4- NPK 75\%+ Compost 5-NPK $100 \%+$ Compost. ( 5 treatments $\times 3$ replicates $=15$ plots $)$ each plot $1.4 \times 1.2 \mathrm{~m}=1.68 \mathrm{~m}^{2}$ cultivated with 32 plants.

\section{Soil and plant samples}

Soil samples were taken after harvest stage from each plot, and then air dried, grinned and passed through $2 \mathrm{~mm}$ sieve and stored for soil analysis. Plant samples were taken at two stages, the first at the flowering stage (the hole plant was taken to analysis and the second was at the harvest stage) where seeds and straw were separated, and stored for analysis. Plant samples were taken from plot field and the vegetative growth parameters were measured (plant height, pod length, fresh and dry weight), and then $\mathrm{NO}_{3}-\mathrm{N}$ was estimated in the fresh plant parts, after that the plant parts were dried at $70^{\circ} \mathrm{C}$ and the dry weight was recorded. The plant parts were grinned to fine powder and $0.2 \mathrm{gm}$ was wet digested with a mixture of sulfuric acid $\left(\mathrm{H}_{2} \mathrm{SO}_{4}\right)$ and perchloric acid $\left(\mathrm{HClO}_{4}\right)$ for the different analysis (i.e., N, P and $\mathrm{K}$ ) 
Methods of soil analysis

- The electrical conductivity of the 1: 5 soil paste extracts was measured, and EC value, $\mathrm{pH}$ value, $\mathrm{CaCo}_{3}$ and organic matter contents were determined according to Sahlemedhin and Taye (2000).

- Particle size distribution, available N, $\mathrm{P}$ and $\mathrm{K}$ in the soil were determined according to the methods of Haluschak (2006) and Reeuwijk (2002).

\section{Plant analysis}

Bean plant samples were oven dried at $70^{\circ} \mathrm{C}$ till constant weight and the dry weight was recorded. The $\mathrm{N}, \mathrm{P}$, and $\mathrm{K}$ concentrations were determined in oven dry plant samples at booting in the whole plant and at harvest in both separated organs of straw and seeds. The oven dry plant samples were grinned and $0.2 \mathrm{gm}$ from each sample was weighted and wet digested. N, P and $\mathrm{K}$ nutrients were measured in the digestive extract and their percentages were calculated on oven dry weight. Nutrients determination were performed as follows :

- $\quad$ Total N, P and K (\%) were determined according to the methods described by Mertens (2005a \& b) and Agrilasa (2002) respectively.

- Chlorophyll content was estimated as the method described by Gavrilenko and Zigalova (2003).

- Total cabohydrates\% was determined according to Ranganna (2001).

All data were statistically analyzed according to the technique of analysis variance (ANOVA) and the least significant difference (L.S.D) method was used to compare the difference between the means of treatment values to the methods described by Gomez and Gomez (1984). All statistical analyses were performed using analysis of variance technique by means of CoSTATE Computer Software.

\section{Results and Discussion}

Effect of mineral fertilizers and compost on Vegetative growth parameter: pod diameter ( $\mathrm{mm})$, pod length (cm), and Plant height $(\mathrm{cm})$ of bean plant

\section{- $\quad$ Pod diameter ( $\mathrm{mm}$ )}

Data tabulated in Table 3 showed that all treatments significantly increased pod diameter of bean plant, the best treatment which gave the highest value and significant increas in pod diameter of bean plant was NPK $100 \%+$ compost recording $12.573(\mathrm{~mm})$ in the season compared to other treatments and the control which recorded the lowest value $10.716(\mathrm{~mm})$ in the season. This result agrees with Lixandru et al. (2010) who found that applied fertilizer in quantities of $50 \mathrm{t}$ and $100 \mathrm{th}-1$ compost to bean and pea improved weight, length and diameter of pods and total beans production, Also, combining organic and inorganic fertilization obtained a proportional increase of production only for the total biomass production. El-Bassiony et al. (2010) reported that increasing NPK application levels with humic acid (organic matter) improved the plant growth, yield and green pod quality of snap bean.

\section{- Pod length (cm)}

Concerning the effect of different treatments on pod length $(\mathrm{cm})$ of bean plant in Table 3 it was found that significant increase was achieved in pod length $(\mathrm{cm})$ of bean plant and the highest value resulted from the treatments NPK $100 \%+$ compost which recorded $12.263(\mathrm{~cm})$ in the season, while the control recorded the lowest value in experiment $10.04(\mathrm{~cm})$ in season. These results are in harmony with those obtaiend by El-Awadi et al. (2011) who found that applied chemical fertilizers (nitrogen ) $100 \%, 65 \%$ and $35 \%$ of the recommended dose increased pod length of Snap Bean (Phaseolus vulgaris L) Plants, the same results were obtained by Saxena et al. (2003)

\section{- $\quad$ Plant height (cm)}

Data in Table 3 showed that all treatments significantly increased plant height of bean plant. Also, the treatment NPK $100 \%+$ compost gave the highest value $(48.317 \mathrm{~cm})$ in the season. While the control decreased plant height which gave the lowest value $(35.77 \mathrm{~cm})$ in the season. These results also agree with Balbhim et al. (2015) who reported that used compost and chemical fertilizers increased plant height of Leguminaceae and found that compost gave higher values followed by chemical fertilizers compared with control. These results may be due to nitrogen used to promote plant growth (Coruzzi and Last, 2000).

Effect of mineral fertilizers and compost on Yield and its components: 100 seeds weight (g) and yield ( $\mathrm{g} / \mathrm{plot}$ )

- 100 seeds weight (g)

Data tabulated in Table 3 show the effect of mineral fertilizers treatment, and compost, 
the control gave the lowest values of 100 seeds weight $(\mathrm{g})$ of bean plant compared to other treatments and it recorded $47.1(\mathrm{~g})$ while treatment NPK $100 \%+$ compost gave the highest values 49.73 (g) of bean plant in the season. These results agree with Kadam and Pathade (2014) who reported that appling $25 \%$ chemical fertilizer with $75 \%$ vermicomposting increased 100 seeds weight $(\mathrm{g})$ of bean plant compared to control plant. Also, Bildirici and Yilmaz (2005) showed that phosphorus enhanced 100 seeds weight $(\mathrm{g})$ of bean plant and played an important role in grain yield.
- $\quad$ Yield (g/plot)

Data in Table 3 showed that all treatments increased yield (g/plot) of bean plant. Also, the treatment NPK $100 \%+$ compost gave the highest values $1681.12(\mathrm{~g})$ in the season. While the control decreased yield $(\mathrm{g} / \mathrm{plot})$ which gave the lowest value $890.25(\mathrm{~g})$ in the season. These results also agree with those obtained by Ngakou et al. (2008) who reported that using compost for common bean (Phaseolus vulgaris) productivity in the field increased the seed yield. Also, Mahmoud et al. (2010) found that appling inorganic nitrogen levels improved yield in bean (Phaseolus vulgaris L.).

TABLE 3. Effect of mineral fertilizers and compost on pod diameter $(\mathrm{mm})$, pod length $(\mathrm{cm})$, Plant height $(\mathrm{cm}), 100$ seeds weight (g) and yield (g/plot) of bean plant

\begin{tabular}{|lccccc|}
\hline Treatment & $\begin{array}{c}\text { Char } \\
\text { Pod diameter } \\
(\mathbf{m m})\end{array}$ & $\begin{array}{c}\text { pod length } \\
(\mathbf{c m})\end{array}$ & $\begin{array}{c}\text { plant } \\
\text { height }(\mathbf{c m})\end{array}$ & $\begin{array}{c}\text { 100 seeds } \\
\text { weight /g }\end{array}$ & $\begin{array}{c}\text { Yield (g/ } \\
\text { plot) }\end{array}$ \\
Control & 10.71633 & 10.04 & 35.77 & 47.10 & 890.25 \\
NPK 75\% & 11.5083 & 11.0033 & 43.1708 & 49.36 & 1121.27 \\
NPK 100\% & 12.398 & 12.20 & 46.006 & 49.66 & 1492.85 \\
NPK 75\%+ compost & 11.6453 & 11.3666 & 45.1666 & 49.66 & 1406.77 \\
NPK 100\%+ compost & 12.573 & 12.2633 & 48.3066 & 49.73 & 1681.12 \\
LSD & 0.07 & 0.22 & 0.37 & 0.42 & 74.28 \\
F test & $* *$ & $* *$ & $* *$ & $* *$ & $* *$ \\
\hline
\end{tabular}

Effect of mineral fertilizers and compost on chemical composition of bean plant

- Nitrogen content of seeds

Data presented in Table 4 showed that all treatments significantly increased nitrogen content in seeds. Also, the highest value of nitrogen content in seeds was with the treatment NPK $100 \%+$ compost $(3.35 \%)$, while the control recorded the lowest value in the experiment $(2.81 \%)$ in season. These results are in line with those of Uyanoz (2007) who found that applied different bioorganic, chemical fertilizers increased nitrogen content in seeds of bean plant. Also, Yadav et al. (2013) noticed higher accumulation rate of available $\mathrm{N}$ in seeds when applying organic matter for bean plant.

\section{- $\quad$ Phosphorus content in seeds}

Data in Table 4 showed the effect of mineral fertilizers and compost on phosphorus content of seeds. The highest value of nitrogen content in seeds was with the treatment NPK 100\%+ compost $(0.378 \%)$ in season, while the control recorded the lowest values in the experiment $(0.344 \%)$ in season. These results are in harmony with those obtained by Turuko and Mohammed (2014) who found response of common bean to different levels of phosphorus fertilizers and also found an increase in the number of seeds and phosphorus content in seeds due to the effect of phosphorus fertilizers. Also, El-Gizawy and Mehasen (2009) found that the interaction between phosphorus and zinc treatments significantly affected phosphorus content in seeds of bean plant.

\section{- $\quad$ Potassium content in seeds}

Data tabulated in Table 4 revealed that all tested treatments gave significant increase in potassium content of seeds compared to control in this respect. It was revealed that the treatments NPK $100 \%+$ compost recorded $2.55 \% \mathrm{~K}$, but the control in the experiment gave the lowest value, $2.05 \% \mathrm{~K}$. The results agree with those obtained by Uyanoz (2007) who reported that the combination between organic manure and chemical fertilizers increased potassium content in seeds of bean plant. Also, Khosro et al. (2010) found that the content of phosphorus and potassium and other minerals in seeds of pea plant increased under

Egypt. J. Soil Sci., Vol. 57, No.3 (2017) 
application of compost and farmyard manure.

\section{- $\quad \mathrm{N} \%$ in leaves}

Data in Table 4 revealed that all treatments under study were superior and significantly increased over control which gave higher values compared to control for nitrogen in leaves. In this respect, the treatment NPK $100 \%$ + compost gave the highest value $(3.75 \% \mathrm{~K})$ in the leaves of bean, while the control gave the lowest value in this respect, it recorded $(3.39 \% \mathrm{~K})$ in the leaves of bean plant. These results are in harmony with those found by Amanullah et al. (2007), who reported increasing leaves contents of $\mathrm{N}$ and $\mathrm{K}$ of snap bean plants by adding $\left(100 \mathrm{~kg} \mathrm{~N} \mathrm{ha}^{-1}\right)$ improving the soil physical and chemical properties by the presence of higher levels of nutrient elements of organic matter. Also, Feleafel and Mirdad (2014) reported that using organic fertilizers; chicken manure and biofertilizer increased nitrogen in pod and leaves of snap bean plant.

- $\quad$ P\% in leaves

Data tabulated in Table 4 showed that all treatments significantly increased phosphorus content in leaves of bean plant. Also, the highest value of phosphorus content in leaves was found with the treatment NPK 100\% + compost $(0.417 \% \mathrm{P})$, while the control recorded the lowest value in the experiment $0.379 \%$. Moghazy et al., 2014 found that application of combinations between compost manure and mineral nitrogen fertilizer increased NPK content in leaves of pea plant. Also, Mohamed and Ebead 2013 applied tri-calcium phosphate in combination with sewage sludge compost resulting in an increase in theNPK content in shoots and leaves of bean plants.

\section{- $\quad K \%$ in leaves}

Concerning the effect of different treatments on potassium $\%$ in the leaves of bean plants in Table 4, results showed a significant increase in potassium in leaves and the highest value of potassium content in the leaves was with the treatment NPK $100 \%+$ compost recording $(2.70 \%$ $\mathrm{K})$, while the control recorded the lowest value in experiment $2.37 \%$. Santos et al. (2001) found

TABLE 4. Effect of mineral fertilizers and compost on chemical composition of bean plant

\begin{tabular}{|lcrrrrrrr|}
\hline & Char. & \multicolumn{2}{c}{ N\% } & \multicolumn{2}{c}{ P\% } & \multicolumn{2}{c}{ K\% } \\
Treat. & seeds & leaves & seeds & leaves & seeds & leaves \\
Control & 2.81 & 3.39 & 0.344 & 0.379 & 2.05 & 2.37 \\
NPK 75\% & 2.99 & 3.44 & 0.351 & 0.391 & 2.16 & 2.43 \\
NPK 100\% & 3.13 & 3.49 & 0.362 & 0.396 & 2.30 & 2.53 \\
NPK 75\%+ compost & 3.25 & 3.66 & 0.373 & 0.407 & 2.39 & 2.60 \\
NPK 100\%+ compost & 3.35 & 3.75 & 0.378 & 0.417 & 2.55 & 2.70 \\
LSD $_{\text {at 5\% }}$ & 0.09 & 0.08 & 0.006 & 0.006 & 2.91 & 0.06 \\
F test & $* *$ & $* *$ & $* *$ & $* *$ & $* *$ & $* *$ \\
\hline
\end{tabular}

increasing leaf contents of $\mathrm{N}$ and $\mathrm{K}$ by applying a source of nitrogen fertilizer and organic material which improved photosynthetic rate and the yield of bean plant.

Effect of mineral $N$ fertilizers and compost on qualitative paramerters of bean plant

- Carbohydrate \% in seeds

Data in Table 5 revealed that treatments increased total carbohydrate $\%$ in seeds of bean plant and the studied treatment which gave the highest value and significant increase in $\mathrm{T}$. carbohydrate was NPK $100 \%+$ compost which recorded $45.02 \%$ in cultivation season. While the control achieved the lowest value $38.31 \%$. These results are in harmony with those found by
Moghazy et al. (2014) who reported that applied mineral nitrogen, compost and micronutrients on pea plant improved Carbohydrate in seeds. ElMansi et al. (2004) reported on pea, that applied compost and nitrogen fertilizer increased $\mathrm{T}$. carbohydrate and protein in seeds which may be due to the high growth and pod high yield of plant fertilized by nitrogen fertilizer combined with compost manure; it may be due to availability of organic nitrogen, which ultimately resulted in better root growth and increased physical activity of roots to absorb the nutrients through decomposition of organic manure that led to an increase in their contents 


\section{- $\quad$ C. protein \% on seeds}

Data in Table 5 showed that effect of mineral fertilizers, and compost on protein $\%$ in seeds which showed that NPK 100\%+ compost treatment increased protein $\%$ in seeds of bean plant and recorded the highest value $(22.44 \%)$ compared to other treatments and control which recorded the lowest value $(17.65 \%)$ in cultivation season. The results agree with those obtained by Kucuk et al. (2011) who found that application of nitrogen with Rhizobium + nitrogen fertilization on bean (Phaseolus vulgaris L.) increased protein in seeds. Also, Uchida (2000) found that in legumes and other leafy vegetables, nitrogen fertilizers improved the quality and quantity of dry matter and protein in plant and seeds. Also, Russel (2008) reported that the legume plants such as bean plant supplies the carbohydrate for bacterial growth while the bacteria fix atmospheric $\mathrm{N}_{2}$ into $\mathrm{NH}_{4}+$ in soil , to be converted into amino acids that can be used by the plant to synthesize proteins for its growth and development.

- Chlorophyll content ( $\mathrm{mg} / \mathrm{g}$ fresh leaves):

Results in Table 5 showed the effect of mineral fertilizers and compost on chlorophyll content in bean which revealed that NPK100\%+compost increased chlorophyll content and recorded the highest value ( $24.45 \mathrm{mg} / \mathrm{g}$ fresh leaves) compared to other treatments and control which recorded the lowest value $(14.96 \mathrm{mg} / \mathrm{g}$ fresh leaves) in cultivaton season. The results agree with those obtained by Awad et al. (2007) who found that nitrogen helps to increase chlorophyll content in the plant, and the same result was observed with Al-Said and Kamal (2008)

TABLE 5. Effect of mineral fertilizers and compost on qualitative paramerters of bean seeds.

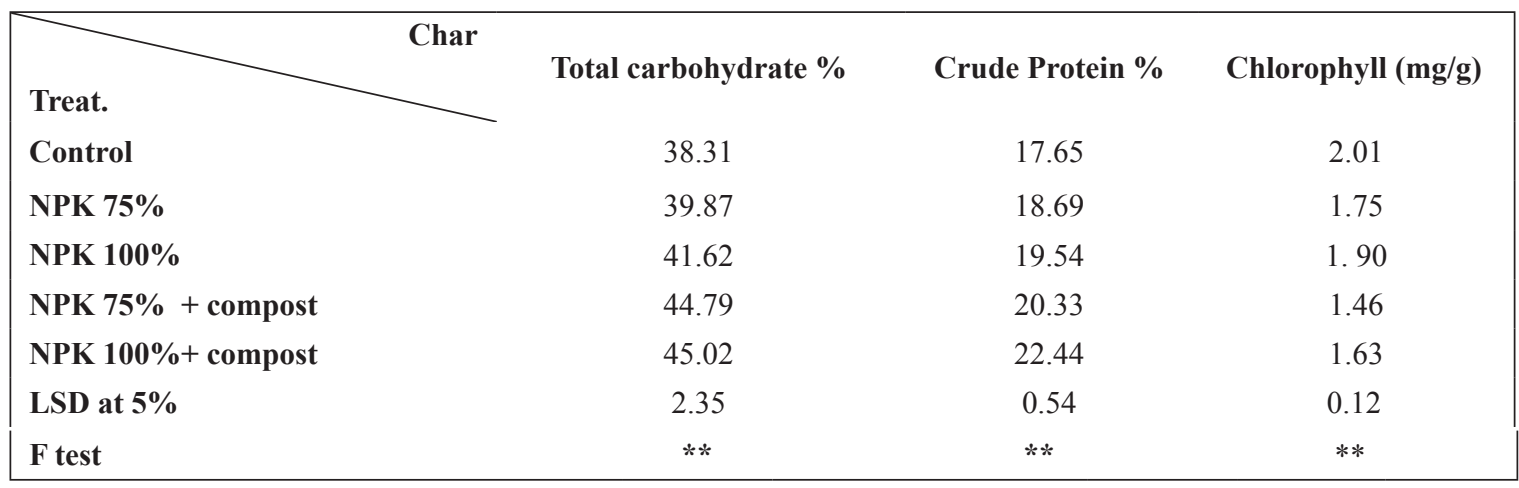

Effect of mineral fertilizers and compost on soil available NPK

- $\quad$ Soil available N (ppm)

Data in Table 6 showed that all treatments significantly increased soil available N. Also the highest value of soil available $\mathrm{N}$ was with the treatment NPK $100 \%+$ compost which recorded $49.90 \mathrm{ppm}$ in cultivation season, while the control recorded the lowest value in the experiment (39.37 $\mathrm{ppm}$ ). These results agree with those obtained by Sharif et al., 2013 who reported that available nitrogen of soil was improved when composts added to soil. Also, Suhane (2007) applied 100 $\mathrm{kg}$ nitrogen fertilizers to soil, only $20-25 \mathrm{~kg}$ is available in soil to plants, while when applied with compost gave highier available $\mathrm{N}$ in soil to plants and showed that exchangeable potassium (K) was over $95 \%$ higher in vermicompost.

\section{- $\quad$ Soil available P (ppm)}

Data in Table 6 showed that all treatments gave a significant increase in soil available $\mathrm{P}$ (ppm) compared to the control in this respect. It was revealed that the treatments NPK 100\% + compost recorded (5.42 ppm P), while control gave the lowest value (4.12 ppm P). The results agree with those obtained by Majumdar et al. (2007) who found that the application of rock phosphate (RP) mixed with different organic materials increased the concentration of phosphorus. Also, Vanlauwe et al. (2000) found that composts with RP released more amounts of acid and alkaline phosphates in soil as compared to other common composts, which may be able to liberate more $\mathrm{P}$ from rock phosphate with rhizosphere acidification during $\mathrm{N}_{2}$ fixation, converting it into available forms in the soil as well as incorporating it as biomass.

\section{- $\quad$ Soil available $K$ (ppm)}

Data in Table 6 showed the effect of mineral fertilizers and compost on soil available $\mathrm{K}$ (ppm) which showed that NPK $100 \%+$ compost increased soil available $\mathrm{K}$ and recorded the highest values (229.4 ppm K) compared to other 
treatments and the control which recorded the lowest value (189.1 ppm K). The results agree with those obtained by Singh and Chauhan (2009) who found that potassium is as effective as chemical fertilizer with continued application of compost (organic nitrogen), it tends to be released at a constant rate from the accumulated humus' and the net overall efficiency of nitrogen over a period of years is considerably greater than $50 \%$ of that of chemical fertilizers. Also, Atiyeh (2000) showed that applied compost and vermicompst to soil increased soil available potassium compared to traditional organic fertilizers.

TABLE 6. Effect of mineral fertilizers and compost on available N, P and K (PPM) in soil cultivated

\begin{tabular}{|l|c|c|c|}
\hline \multicolumn{1}{c|}{ Char. } & \multicolumn{2}{|c|}{ Soil } & \\
Treatment & Avail. N PPM & Avail. P PPM & Avail. K PPM \\
Control & 39.37 & 4.12 & 189.1 \\
NPK 75\% & 41.80 & 4.16 & 198.3 \\
NPK 100\% & 44.30 & 4.52 & 209.0 \\
NPK 75\%+ compost & 46.20 & 4.96 & 218.0 \\
NPK 100\% + compost & 49.90 & 5.42 & 229.4 \\
LSD & 0.98 & 0.26 & 3.29 \\
F test & $* *$ & $* *$ & $* *$ \\
\hline
\end{tabular}

\section{$\underline{\text { References }}$}

Agrilasa (2002) "Handbook on Feeds and Plant Analyses", AGRILASA, Pretoria. South Africa.

Al-Said, M.A. and A.M. Kamal (2008) Effect of foliar spray with folic acid and some amino acids on flowering, yield and quality of sweet pepper. $J$. Agric. Sci. Mansoura Univ. 33 (10), 7403 - 7412.

Amanullah, M.M., Somasundaram, E., Vaiyapuri, K and Sathyamoorthi, K. (2007) Poultry manure to crops -A Review. Agric. Rev., 28, 216-222.

Atiyeh, R.M., Dominguez, J., Sobler, S. and Edwards, C.A. (2000) Changes in biochemical properties of cow manure during processing by earthworms (Eisenia andrei) and the effects on seedling growth, Pedobiologia., 44, 709-724.

Awad, El-M.M., Abd El-Hameed, A.M. and Shall, Z.S. (2007) Effect of glycine, lysine and nitrogen fertilizer rates on growth, yield and chemical composition of potato. J. Agric. Sci. Mansoura Univ., 32 (10), 8541 - 8551.

Balbhim, L. C., Mangesh, M. V. and Bhimashankar, R. P. (2015) Effects of organic and chemical fertilizers on cluster bean (Cyamopsis tetragonolobus). European Journal of Experimental Biology, 5 (1), 34-38.
Bildirici, N. and Yilmaz, N. (2005) The effects of different nitrogen and phosphorus doses and bacteria inoculation (Rhizobium phaseoli) on the yield and yield components of field bean (Phaseolus vulgaris L.), Journal of Agronomy, 4, 207-215.

Bokhtiar, S. M. and Sakurai, K. (2005) Effects of organic manure and chemical fertilizer on soil fertility and productivity of plant and ratoon crops of sugarcane. Archives of Agronomy and Soil Science, 51, 325 - 334.

Coruzzi, G. and Last, R. (2000) Amino acids. In : "Biochemistry and Molecular Biology of Plants". B. Buchanan, W. Gruissem, R. Jones (Ed.). Amer. Soc. Plant Biol., Rockville, MD, USA.358-410.

Dewis, J. and Freitas, F. (1970) "Physical and Chemical Methods of Soil and Water and Analsis" Food and Agriculture Organization of United Nations, Rome.

El-Awadi, M. E., El-Bassiony, A. M., Fawzy Z. F. and El-Nemr, M. A. (2011) Response of snap pean (Phaseolus vulgaris L) plants to nitrogen fertilizer and foliar application with methionine and tryptophan]. Nature and Science, 9 (5), 87-94

El-Bassiony, A.M., Fawzy; Z.F., Abd El-Baky,M.M.H. and Mahmoud, Asmaa, R. (2010) Response of snap bean plants to mineral fertilizers and humic acid application. Res. J. of Agric. and Biol. Sci., 6 (2),

Egypt. J. Soil Sci., Vol. 57, No.3 (2017) 
$169-175$

El-Bramawy, M.A.S.A. and Shaban, W. I. (2010) Effects potassium fertilization on agronomic characters and resistance to chocolate spot and rust diseases in faba bean. Tunisian Journal of Plant Protection., 5, 131-150.

El-Gizawy, N.Kh.B and Mehasen, S.A.S. (2009) Response of Faba Bean to Bio, Mineral Phosphorus Fertilizers and Foliar Application with Zinc. World Applied Sciences Journal, 6 (10), 1359-1365.

El-Mansi, A. H. M., Arisha and El-Kassas, A. I. (2004) Effect of organic manure sources on growth, chemical contents and yield of pea plants under sandy soil Condition. Zagazig J. Agric. Res. (5), 2097- 2121.

FAO. (2010) Food and Agriculture Organization of the United Nations. Faostat: Statistical Database,

Feleafel, M.N. and Mirdad, Z.M. (2014) Influence of organic nitrogen on the snap bean grown in sandy soil. Int. J. Agric. Biol. 16, 65-72.

Gavrilenko V. F. and Zigalova, T. V. (2003)The Laboratory Manual for the Photosynthesis" Academia, Moscow. 256 cтр. (in Russian).

Gomez, K. A. and Gomez, A. A. (1984) "Statistical Procedures for Agricultural Research' $2^{\text {nd }}$ ed, John Wiley and Sons. Inc. New York.

Haluschak, P. (2006) "Laboratory Methods of Soil Analysis". Canada-Manitoba Soil Survey. April

Kadam, D. and Pathade, G. (2014) Effect of tendu (Diospyros melanoxylon Rox B.) leaf vermicompost on growth and yield of French bean (Phaseolus vulgaris L.). Int. J. Recycl Org. Waste Agricult. 3 (44), 2-7.

Khosro, M. A., Ghalavand, M. and Aghoalikhoni (2000) Effect of organic matter and bio-fertilizers on bean quality and biological nitrogen fixation. World Academy Sci., Eng.and Tech. (44) 212-215.

Kucuk, C. (2011) Inoculation with Rhizobium spp. in kidney bean (Phaseolus vulgaris L.) varieties Žemdirbystè. Agriculture, 98 (1), 49-56.

Liang, W., Wu, X., Zhang, S., Xing, Y. and Wang, R. (2011) Effect of organic amendments on soil water storage in the aeolian sandy land of northeast

Egypt. J. Soil Sci., Vol. 57, No.3 (2017)
China. Proceedings of the Electrical and Control E Engineering (ICECE), International Conference on 16th-18th Sept. 2011. pp. 1538-1540.

Lixandru, B., Pătroescu,V., Leonte,E.P., Dragomir,N., Pricop,A., Morariu,F and Popescu, D. (2010) Testing the Fertilizer Effect of Compost Produced by Anaerobic Fermentation of Sewage Slud. Animal Science and Biotechnologies. 43 (2), 98-102.

Mahmoud A.R., El-Desuki, M. and Abdel-Mouty, M. M. (2010) Response of snap bean plants to bio-fertilizer and nitrogen level application. International Journal of Academic Research, 2, 3. Ministry of Agriculture (2004). Strategy for Revitalizing Agriculture., 2004-2014. pp. 82.

Majumdar, B., Venkatesh, M.S., Kumar.K. and Patiram (2007) Effect of rock phosphate, superphosphate and their mixtures with FYM on soybean and soil$\mathrm{P}$ pools in a typic hapludalf of Meghalaya. $J$. Indian Society of Soil Sci., 55 (2), 167-174.

Mertens, D. (2005a) AOAC official method 922.02. "Plants Preparation of Laboratuary Sample. Official Methods of Analysis", $18^{\text {th }}$ ed., North Frederick Avenue, Gaitherburg, Maryland, 1-2 pp.

Mertens, D. (2005b) AOAC Official method 975.03. "Metal in Plants and Pet Foods. Official Methods of Analysis", 18 ${ }^{\text {th }}$ ed., North Frederick Avenue, Gaitherburg, Maryland. 3-4 pp.

Moghazy, A. M., El. Saed, S. M and Awad E. S. M. (2014) The Influence of Boron Foliar Spraying with Compost and Mineral Fertilizers on Growth, Green pods and Seed Yield of Pea. Nature and Science, 12 (7), 50-57.

Mohamed, A.I. and Ebead, B.H. (2013) Effect of irrigation with magnetically treated water on faba bean growth and composition International Journal of Agricultural Policy and Research, 1 (2) 024-040.

Ngakou, A., Megueni, C., Noubissie, E. and Tchuenteu, L. (2008) Evaluation of the physico-chemical properties of cattle and kitchen manuresderived composts and their effects on field grown phaseolus vulgaris L. Int. J. Sustain. Crop Prod. 3(5),13-22.

Pagliai, M., Vignozzi, N. and Pellegrini, S. (2004) Soil structure and the effect of management practices. Soil Tillage Res. 79, 131-143. 
Ranganna, S. (2001) "Analysis and Quality Control for Fruits and Vegetable Products". Tata Mc Grawhill Publication, New Delhi.

Reeuwijk, L. P. (2002) "Procedures for Soil Analysis". Inter. Soil Ref. and Info. Center. Food and Agric. Organization of the United Nations

Russel. S.J.E. (2008) Soil conditions and plants growth, Daya Book.

Sahelemedhin, S. and Taye, B. (Editors) (2000) "Procedures for Soil and Plant Analysis". National Soil Res. Center, Addis Ababa, Ethiopia.

Santos, G.M., Oliveira, A.P., Silva, J.L., Alves, E.U. and Costa, C.C. (2001) Characteristics and yield of snap-bean pod in function of sources and levels of organic matter. Hortic. Bras. 19, 30-35.

Saxena, K.K., Arun-Srivastava and Singh, R.B. (2003) Response of French bean to nutrient application (NPK) in relation to physiological traits and their consequent effect on yield. Farm Sci. J. 12 (2), 150152.

Sharif, M., Burni, T., Wahid, F., Khan, F., Khan, S., Khan, A., Shah, A. (2013) Effect of rock phosphate composted with organic materials on yield and phosphorus uptake of wheat and mung bean crops. Pak. J. Bot. 45 (4), 1349-1356.

Shehata, S.A., Ahmed, Y.M., Emad, A.S. and Omaima S.D. (2011) Influence of Compost Rates and Application Time on Growth, Yield and Chemical Composition of Snap Bean (Phaseolus vulgaris L) Australian Journal of Basic and Applied Sciences 5 (9), 530-536.

Singh, N.I. and Chauhan, J.S. (2009) Response of French Bean (Phaseolus vulgaris L.) to Organic Manures and Inorganic Fertilizer on Growth \& Yield Parameters under Irrigated Condition. Nature and Science, 7 (5), 52-54.

Sinha and Rajiv, K. (2003) Vermicompost: A Powerful Crop Nutrient over the Conventional Compost \& Protective Soil Conditioner against the Destructive Chemical Fertilizers. Am-Euras. J. Agric. \& Environ. Sci. 5 (S), 1-40

Suhane, R.K. (2007) Vermicompost (In Hindi); Pub. Of Rajendra Agriculture University, Pusa, Bihar; pp: 88(www.kvksmp.org) (Email: info@kvksmp.org).
Turuko, M. and Mohammed, A. (2014) Effect of different phosphorus fertilizer rates on growth, dry matter yield and yield components of common bean (Phaseolus vulgaris L.). World Journal of Agricultural Research, 2 (3), 88-92.

Uchida, R. (2000) Essential nutrients for plant growth: Nutrient functions and deficiency symptoms. Plant nutrient management in Hawaii's soils. College of Tropical Agriculture and Human Resources, University of Hawaii at Manoa., 31-55.

Uyanoz, R. (2007) The effects of different bio-organic, chemical fertilizers and their combination on yield, macro and micro nutrition content of dry bean (Phaseolus vulgaris L.). Int. J. Argic. Res. 2, 115125.

Vanlauwe, B. J., Diels, N., Sanginga, R.J., Carsky, J., Deckers and Merckx. R. (2000) Utilization of rock phosphate by crops on representative top sequence in the Northern Guinea savanna zone of Nigeria. Soil Biol. Biochem., 32, 2079-2090.

Yadav, S. K., Subhash, B., Yadav, M. K., Singh, G. S. Y. and Suresh, P. (2013) A review of Organic Farming for Sustainable Agriculture in Northern India. Institute of Agricultural Sciences, Banaras Hindu University., 215-223.

(Received : 24 / 2 /2016; acecpted : 15 / 3 /2016) 


\section{التأثير المتكامل للمخصبات على الفاصوليا المزروعة في التربة الرسوبية}

كريم فكري فودة ، أيمن محمد الغمري ، زكريا مسعد الصيرفي و ابراهيم حمودة عبدالله خليويط

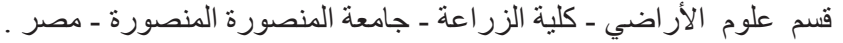

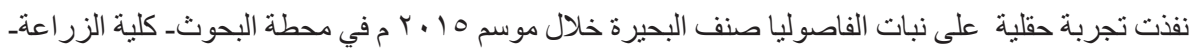

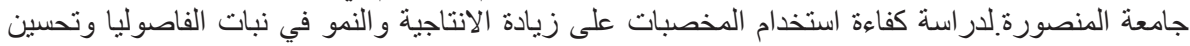

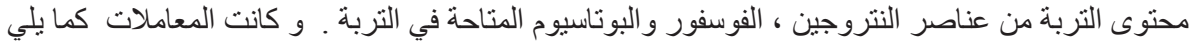

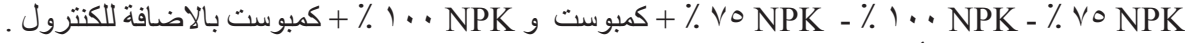

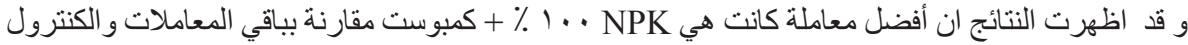

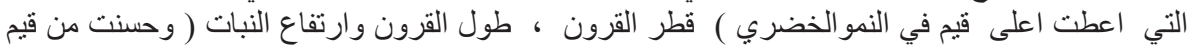

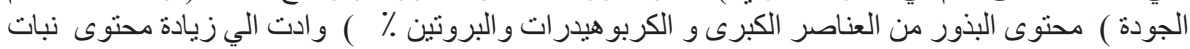

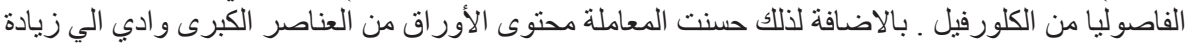

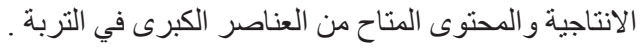

